\title{
PENERAPAN RESTORATIVE JUSTICE DALAM PROSES PERKARA TINDAK PIDANA PENGERUSAKAN DIHUBUNGKAN DENGAN PERATURAN JAKSA AGUNG TENTANG PENGHENTIAN PENUNTUTAN BERDASARKAN KEADILAN RESTORATIF (Studi di Kejaksaan Negeri Pematangsiantar)
}

\author{
Sahat Benny Risman Girsang', Erni Juniria Harefa ${ }^{2}$, Pondang Hasibuan ${ }^{3}$, July \\ Esther $^{4}$ \\ Program Studi Magister Hukum \\ Program Pascasarjana \\ Universitas HKBP Nommensen, Medan-Sumatera Utara-Indonesia \\ e-mail: sahatbennyrg@yahoo.com
}

\begin{abstract}
Settlement of criminal cases through restorative justice in stage two (2) or since the handing over of responsibility for suspects and evidence to the Public Prosecutor has been regulated in the Attorney General's Regulation No. 15 of 2020 concerning Termination of Prosecution Based on Restorative Justice. The legality of the application of restorative in Indonesia has been used in Law No. 11 of 2012 concerning the Juvenile Justice System (SSPA) and the Circular Letter of the Chief of Police No. 8 of 2018 concerning the Application of Restorative Justice before the start of the investigation sent to the Public Prosecutor. a law enforcement in a slow direction because law enforcement is carried out at various levels from the Police, Attorney General's Office, District Courts, High Courts and even to the Supreme Court. In the end it has an impact on the accumulation of cases that are not small in number in court. The purpose of this study is to find out the application and problems that occur in the application of restorative justice through efforts to stop prosecution in the process of resolving cases of criminal acts of vandalism associated with the Attorney General's Regulation No. 15 of 2020 concerning Termination of Prosecution Based on Restorative Justice. This research is normative-empirical juridical using a case approach and a statutory approach. Data collection techniques using primary data are field interviews at the Pematang Siantar District Attorney and library research to obtain secondary data. Referring to the principle of fast, simple and low cost justice, PERJA No. 15 of 2020 concerning Termination of Prosecution Based on Restorative Justice has been accommodated, especially in cases of destruction by making peace between victims and suspects, and the peace process is carried out voluntarily, with deliberation and consensus, without pressure, coercion and intimidation. In this peace process the facilitator is the Public Prosecutor, this is because there is no interest and connection with the case, against the victim and the suspect. In the implementation of PERJA No. 15 of 2020, it turns out that there are many obstacles, including the lack of understanding among law enforcement regarding restorative justice, lack of infrastructure, and public misunderstanding.

Keywords : Restorative Justice, Prosecution and Vandalism
\end{abstract}

\begin{abstract}
Abstrak
Penyelesaian perkara pidana melalui keadilan restoratif pada tahap dua (2) atau pada sejak penyerahan tanggungjawab atas tersangka dan barang bukti kepada Jaksa Penuntut Umum telah diatur di dalam Perturan Jaksa Agung No 15 Tahun 2020 tentang Penghentian Penuntutan Berdasarkan Keadilan Restoratif. Legalitas penerapan restoratif di Indonesia telah
\end{abstract}


digunakan di dalam Undang-Undang No 11 Tahun 2012 tentang Sistem Peradilan Anak (SPA) dan Surat Edaran Kapolri No 8 Tahun 2018 tentang Penerapan Keadilan Restoratif sebelum dimulainya penyidikan dikirimkan kepada Jaksa Penuntut Umum.Penyelesaian perkara melalui sistem peradilan merupakan suatu penegakan hukum (law enforcement) ke arah jalur lambat karena penegakan hukum melalui berbagai tingkatan dari Kepolisian, Kejaksaan, Pengadilan Negeri, Pengadilan Tinggi bahkan sampai ke Mahkamah Agung. Pada akhirnya berdampak pada penumpukan perkara yang jumlahnya tidak sedikit di pengadilan. Tujuan penelitian ini adalah untuk mengetahui penerapan serta problematika yang terjadi dalam penerapan keadilan restoratif melalui upaya penghentian penuntutan dalam proses penyelesaian perkara tindak pidana pengerusakan dihubungkan dengan Peraturan Jaksa Agung No 15 Tahun 2020 tentang Penghentian Penuntutan Berdasarkan Keadilan Restoratif. Penelitian ini adalah bersifat yuridis normatif-empiris dengan menggunakan pendekatan kasus dan pendekatan perundang-undangan.Tehnik pengumpulan data dengan menggunakan data primer yaitu dengan mengadakan wawancara di Kejaksaan Negeri Pematang Siantar dan penelitian kepustakaan untuk mendapatkan data sekunder. Merujuk kepada asas peradilan cepat, sederhana dan biaya ringan, PERJA No 15 Tahun 2020 tentang Penghentian Penuntutan Berdasarkan Keadilan Restoratif telah diakomodir terutama dalam perkara pengerusakan dengan melakukan perdamaian yang dilakukan antara korban dan para tersangka, dan proses perdamaian tersebut dilakukan dengan sukarela, dengan musyawarah dan mufakat, tanpa tekanan, paksaan dan intimidasi. Dalam proses perdamaian ini yang menjadi fasilator adalah Jaksa Penuntut Umum, hal ini dikarenakan tidak adanya kepentingan dan keterkaitan dengan perkara, terhadap korban dan tersangka. Dalam pengimplementasian PERJA No 15 Tahun 2020 ternyata mengalami banyak kendala antara lain belum adanya kesepahaman diantara penegak hukum tentang keadilan restoratif, kekurangan infrastruktur, dan ketidakpahaman masyarakat. Kata Kunci : Restorative Justice, Penuntutan dan Pengerusakan

\section{A. Pendahuluan}

Carl Von Savigny menyatakan hukum tidak dibuat melainkan tumbuh bersama masyarakat, ${ }^{1}$ sehingga kesadaran hukum dan nilai-nilai yang tumbuh di masyarakat, sangat berperan penting dalam penegakan hukum. Hukum selalu diperuntukan bagi komunitas masyarakat tertentu oleh sebab itu hukum hukum merupakan pencerminan dari masyarakat tersebut. ${ }^{2}$ Nilai-nilai kearifan lokal telah membentuk budaya hukum dalam masyarakat. Keberadaan hukum dalam berbagai kelompok masyarakat diharapkan mampu menjalankan fungsi hukum itu sendiri sebagai sarana penyelesaian sengketa, sarana kontrol sosial, sebagai sarana social engineering, sarana emansipasi masyarakat, sarana legitimasi dan pengontrol terhadap perubahan-perubahan atau sebagai sarana pendistribusian keadilan. ${ }^{3}$

Oleh karena itu tujuan hukum yang ingin adalah kedamaian, ketentraman dan ketertiban dalam masyarakat, terutama masyarakat yang kompleks dan majemuk seperti Indonesia. Ketiga nilai-nilai tersebut juga terkandung di dalam Pancasila. Nilai nilai tersebut dapat digunakan sebagai landasan filosofis penerapan Restorative Justice untuk penyelesaian perkara pidana melalui mekanisme penghentian penuntutan berdasarkan keadilan Restoratif. Pembagunan sistem hukum pidana nasional memerlukan ide dasar yang bertitik tolak dari ide keseimbangan dan konsep pembagunan, maka setiap pembangunan sistem hukum mengarah

\footnotetext{
${ }^{1}$ Lili Rasyidi, 2007, Pengantar Filsafat Hukum, Mandar Maju, Bandung, hlm. 63.

${ }^{2}$ Satjipto Raharjo, 2009, Hukum dan Perilaku, Hidup Baik Adalah Dasar Hukum Yang Baik, Kompas, Jakarta, hlm. 16.
} 
pada ide dasar Pancasila sebagai landasan sistem hukum nasional dan keseimbangan tujuan pembagunan nasional. Ide dasar Pancasila harus dipahami sebagai nilai-nilai yang tercermin di dalam sila-sila Pancasila seperti paradigma Ketuhanan (moral religious), paradigma Kemanusiaan(humanistik), paradigma Kebangsaan (persatuan/nasionalistik), paradigma kerakyatan/demokrasi, dan paradigma keadilan sosial. Ide-ide paradigma tersebut dapat dikelompokkan dalam tiga (3) nilai keseimbangan berupa nilai Ketuhanan (moral-religius), nilai kemanusian (humanistik), dan nilai kemasyarakatan (nasionalistik, demokratik dan keadilan sosial).

Implemetasi dari ide keseimbangan dan konsep pengayoman adalah berkaitan dengan konsep Restoratif Justice merupakan proses penyelesaian yang dilakukan di luar sistem peradilan pidana (Criminal Justice System) dengan melibatkan korban, pelaku, masyarakat serta pihak-pihak yang berkepentingan dengan suatu tindak pidana yang terjadi untuk mencapai kesepakatan dan penyelesaian. Restoratitif justice adalah suatu penyelesaian secara adil yang melibatkan pelaku, korban dan keluarga mereka dan pihak lain yang terkai dengan suatu tindak pidana, secara bersama-sama mencari penyelesaian terhadap tindak pidana tersebut dan implikasinya, dengan menekankan pemulihan dan bukan pembalasan.

Ide dasar dari adanya alternatif penyelesaian dalam perkara pidana adalah dikaitkan dengan sifat hukum pidana itu sendiri. Van Bammelem berpendapat, bahwa hukum pidana itu merupakan ultimum remedium sebaiknya ada pembatasan, artinya kalau bagian lain dari hukum itu tidak cukup menegaskan norma-norma yang diakui oleh hukum, barulah hukum pidana diterapkan. Ancaman pidana merupakan suatu ultimum remedium, (upaya terakhir). Hal ini berarti bahwa ancaman pidana akan ditiadakan, tetapi selalu harus mempertimbangkan untung ruginya ancaman pidana itu, dan harus menjaga agar jangan sampai obat yang diberikan lebih jahat daripada penyakitnya. ${ }^{4}$

Perkara pidana secara prinsip tidak dapat diselesaikan dengan restorative justice, namun dalam praktek sering juga perkara pidana diselesaikan melalui proses mediasi yang merupakan inisiatif penegak hukum sebagai bagian penyelesaian perkara. ${ }^{5}$ Berbicara mengenai legalitas penerapan restorative justice di Indonesia telah dijumpai dalam Undang-Undang Nomor 11 Tahun 2012 tentang Sistem Peradilan Pidana Anak (SPPA). Selain itu terdapat pula Nota Kesepakatan Bersama Ketua Mahkamah Agung Republik Indonesia, Menteri Hukum dan Hak Asasi Manusia Republik Indonesia, Jaksa Agung Republik Indonesia, dan Kepala Kepolisian Negara Republik Indonesia tentang Pelaksanaan Penerapan Penyesuaian Batasan Tindak Pidana Ringan dan Jumlah Denda, Acara Pemeriksaan Cepat, Serta Penerapan Keadilan Restoratif Nomor 131/KMA/SKB/X/2012, M.HH-o7.HM.03.02, KEP-o6/E/EJP/10/2012, $\mathrm{B} / 39 / \mathrm{X} / 2012$ Tahun 2012. Nota Kesepakatan Bersama ini merupakan suatu pelaksanaan Peraturan Mahkamah Agung Republik Indonesia No.2 Tahun 2012 (Perma Nomor 2 Tahun 2012) tentang Penyesuaian Batasan Tindak Ringan dan Jumlah Denda dalam KUHP ke seluruh aparat penegak hukum. Selaras dengan peraturan diatas Kejaksaan Agung dalam kedudukannya sebagai wakil negara dalam bidang penuntutan telah menerbitkan Peraturan Kejaksaan Agung No 15 Tahun 2020 tentang Penghentian Penututan Berdasarkan Keadilan Restorative (disingkat PERJAN No 15 Tahun 2020).

Kejaksaan Republik Indonesia sebagai Lembaga Penunutut juga menginsyaratkan bahwa Lembaga Kejaksaan berada pada posisi sentral dengan peran strategis dalam pamantapan ketahanan bangsa. Kejaksaan berada diporos dan menjadi filter antara proses penyidikan dan

\footnotetext{
${ }^{4}$ Andi Hamzah, 2008, Asas-Asas Hukum Pidana, Edisi Revisi, Rineka Cipta, Jakarta, hlm 10.

${ }^{5}$ Mansyur Ridwan, 2010, Mediasi Penal Terhadap Perkara KDRT (Kekerasan Dalam Rumah Tangga), Yayasan Gema Yustisia Indonesia, Jakarta, hlm. 166.
} 
proses pemeriksaan dipersidangan serta juga sebagai pelaksana ketetapan dan keputusan pengadilan. Lembaga Kejaksaan sebagai proses pengendali proses perkara (Dominus Litis), karena hanya Institusi Kejaksaan yang dapat menentukan apakah suatu kasus dapat diajukan ke pengadilan atau tidak berdasarkan alat bukti yang sah menurut Hukum Acara Pidana. ${ }^{6}$ Wewenang penuntutan dipegang oleh Penuntut Umum sebagai monopoli, artinya tidak ada badan lain yang boleh melakukan wewenang tersebut. Ini disebut dominus litis di tangan Penuntut Umum atau Jaksa.

Dalam kedudukannya Kejaksaan Republik Indonesia telah menjadi lembaga yang melaksanakan kekuasaan negara di bidang penuntutan harus dilakukan berdasarkan keadilan, kemanfaatan, dan kepastian hukum dengan tetap menghargai nilai dan prinsip hukum dalam peraturan perundang-undangan. Selain itu juga Kejaksaan dalam kedudukannya melakukan penuntutan, perlu diarahkan menuju reorientasi pembaharuan hukum pidana, mempertimbangkan tingkat ketercelaan, sikap batin pelaku, kepentingan hukum yang dilindungi, kerugian atau akibat yang ditimbulkan, serta memperhatikan rasa keadilan masyarakat termasuk kearifan lokal. Berdasarkan latar belakang yang telah diuraikan diatas maka perumusan masalah dalam penelitian ini adalah pertama, bagaimanakah penerapan Restorative Justice dalam proses penyelesaian perkara tindak pidana pengerusakan di Lingkup Kejaksaan Negeri Pematang Siantar dihubungkan dengan Peraturan Jaksa Agung No 15 Tahun 2020 tentang Penghentian Penuntutan berdasarkan keadilan restoratif ? Kedua, bagaimana problematika yang dihadapi penerapan Keadilan Restoratif, dalam proses penyelesaian tindak pidana pengerusakan di lingkup Kejaksaan Negeri Pematang Siantar dihubungkan ke Peraturan Jaksa Agung No 15 Tahun 2020 berdasarkan keadilan Restoratif?

\section{B. Metode Penelitian}

Penelitian dapat diartikan sebagai cara mencari kebenaran melalui metode ilmiah, sedangkan metode ilmiah adalah prosedur untuk mendapatkan pengetahuan yang disebut ilmu. ${ }^{7}$ Hakikat penelitian mempunyai fungsi menemukan, mengembangkan atau menguji kebenaran suatu pengetahuan, ${ }^{8}$ dan dalam upaya mengkaji, mempelajari atau menyelidiki suatu permasalahan, untuk memperoleh pengetahuan teoritik yang dapat memperkaya khasanah ilmu dan/atau digunakan untuk pemecahan permasalahan yang sedang dihadapi, Adapun metode yang digunakan dalam penelitian ini adalah bersifat yuridis normatif-empiris Sesuai dengan jenis penelitian yang bersifat yuridis normatif empiris maka sumber data yang digunakan adalah data primer dan data sekunder.

Data Primer yaitu data yang didapat langsung dari sumber pertama yang terkait dengan permasalahan yang akan dibahas dengan melakukan wawancara terstruktur baik dengan para pihak yang berperkara maupun dengan informan yang berasal dari Kejaksaan Negeri Pematang Siantar dalam hal penerapan Restorative Justice dalam tindak pidana pengerusakan. Data Sekunder yaitu data yang diperoleh dengan melakukan penelitian kepustakaan terhadap bahan penelitian yang digunakan yang meliputi bahan hukum primer, seperti kasus, bahan hukum sekunder dan bahan hukum tersier.

Selanjutnya data primer dan data sekunder yang diperoleh dinalisis secara kualitatif dengan mengumpulkan data primer dan data sekunder yang didalamnya terdiri dari bahan

\footnotetext{
${ }^{6}$ Simamora, Janpatar., Kepastian Hukum Pengajuan Kasasi oleh Jaksa Penuntut Umum Terhadap Vonis Bebas, Jurnal Yudisial, Komisi Yudisial RI, Vol. 7 No. 1 April 2014, hlm. 1-17.

${ }^{7}$ Yujun S. Suriasumantri, 1999, Filsafat Ilmu Sebuah Pengantar Populer, Cet Keduabelas, Pustaka Sinar Harapan, Jakarta, hlm. 115

${ }^{8}$ Rianto Adi, 2005, Metode Penelitian Sosial dan Hukum, Cet Kedua, Granit, Jakarta, hlm 3
} 
hukum primer, bahan hukum sekunder dan bahan hukum tersier. Berdasarkan data yang diperoleh dan kemudian dibandingkan dengan hasil penelitian yang dilakukan akan dijadikan sebagai dasar dalam rangka menarik kesimpulan.

\section{Pembahasan}

\section{Pengertian Tindak Pidana Pengerusakan}

Dalam KUHP tindak pidana Pengerusakan dan Penghancuran Benda (verneiling of beschadiging van goerderen), diatur di dalam Pasal 406 KUHP -Pasal 412 KUHP. Pengerusakan merupakan tindak pidana yang mengandung unsur merusak atau tingkah laku yang mengandung sifat demikian terhadap suatu harta benda. Maka untuk lebih jelasnya dibawah ini akan dipaparkan berbagai tindak pidana yang dapat dikualifikasikan sebagai tindak pidana perusakan terhadap barang. Tindak kejahatan dalam bentuk penghancuran dan pengrusakan dibedakan mejadi lima macam yaitu:

1. Penghancuran dan Pengerusakan dalam bentuk pokok;

2. Penghancuran atau pengerusakan ringan;

3. Penghancuran atau perusakan bagunan jalan kereta api, telegraf, telepon dan listrik (sesuatu yang digunakan untuk kepentingan umum )

4. Penghancuran atau pengerusakan tidak dengan sengaja

5. Penghancuran atau pengerusakan terhadap bagunan dan alat pelayaran

Pengerusakan dan penghancuran benda dalam bentuk pokok diatur di dalam Pasal 406 KUHP, merumuskan sebagai berikut :

1. Barang siapa dengan sengaja dan melawan hukum menghancurkan, merusakkan, membikin tidak dapat dipakai atau menghilangkan suatu benda yang seluruhnya atau sebagian adalah milik orang lain, diancam dengan pidana penjara paling lama 2 tahun 8 bulan atau denda paling banyak Rp 4.500,00.

2. Dijatuhkan pidana yang sama terhadap orang yang dengan sengaja dan melawan hukum membunuh, merusakkan, membikin tidak dapat dipergunakan atau menghilangkan hewan yang seluruhnya atau sebagian milik orang lain.

Supaya dapat dihukum, menurut pasal ini harus dibuktikan :

1. 1. Bahwa terdakwa telah membinasakan, merusakkan, membuat sehingga tidak dapat dipakai lagi atau menghilangkan sesuatu.

2. Bahwa pembinasaan dan sebagainya itu dilakukan dengan sengaja dan dengan melawan hukum.

3. Bahwa barang itu harus sama sekali atau sebagian kepunyaan orang lain.

4. Yang dihukum menurut pasal ini tidak saja mengenai barang, tetapi juga mengenai binatang.

\section{Pengertian Restorative Justice}

Tony F. Marshall, Restorative Justice adalah sebuah proses dimana semua pihak yang berkepentingan dalam pelanggaran tertentu bertemu bersama untuk menyelesaikan secara bersama bagaimana menyelesaikan akibat dari pelanggaran tersebut demi kepentingan masa depan. Selanjutnya John Braithwhite berpandangan, bahwa restorative justice adalah proses dimana semua pihak yang terlibat pelanggaran tertentu bersama-sama memecahkan secara kolektif bagaimana untuk menghadapi akibat pelanggaran dan implikasinya pada waktu yang 
akan datang. Lebih lanjut dikatakan oleh John Braithwaite, bahwa restorative justice bertujuan memulihkan harmoni atau keseimbangan karena hukum telah ditegakkan. ${ }^{9}$

Pengertian Keadilan Restoratif menurut PERJA No. 15 Tahun 2020 Tentang Penghentian Penuntutan Berdasarkan Keadilan Restoratif Pasal 1 Ayat (1), yaitu: "Keadilan Restoratif adalah penyelesaian perkara tindak pidana dengan melibatkan pelaku, Korban, keluarga pelaku/ Korban, dan pihak lain yang terkait untuk bersama-sama mencari penyelesaian yang adil dengan menekankan pemulihan kembali pada keadaan semula, dan bukan pembalasan." Restorative justice memandang bahwa:

1. Kejahatan adalah pelanggaran terhadap rakyat dan hubungan antar warga masyarakat.

2. Pelanggaran menciptakan kewajiban.

3. Keadilan mencakup para korban, para pelanggar, dan warga masyarakat di dalam suatu upaya untuk meletakkan segala sesuatunya secara benar.

4. Fokus sentral: Para korban membutuhkan pemulihan kerugian yang dideritanya (baik secara fisik, psikologis, dan materi) dan pelaku bertanggung jawab untuk memulihkannya (pada umumnya dengan cara pengakuan bersalah dari pelaku, permohonan maaf dan rasa penyesalan dari pelaku dan pemberian kompensasi ataupun restitusi).

Prinsip dasar yang menonjol dari restorative justice terkait hubungan antara kejahatan, pelaku, korban, masyarakat dan negara, yaitu:

1. Kejahatan ditempatkan sebagai gejala yang menjadi bagian dari tindakan sosial, bukan sekedar pelanggaran pidana.

2. Restorative Justice adalah teori peradilan pidana yang fokus pada pandangan yang melihat bahwa kejahatan sebagai tindakan oleh pelaku terhadap orang lain atau masyarakat daripada terhadapnegara.

3. Kejahatan dipandang sebagai tindakan yang merugikan orang lain dan merusak hubungan sosial.

4. Munculnya ide restorative justice sebagai kritik atas penerapan sistem peradilan pidana yang dianggap tidak efektif dalam menyelesaikan konflik sosial.

Pasal 30 Ayat (1) Huruf a UndangUndang Nomor 16 Tahun 2004 Tentang Kejaksaan Republik Indonesia menyatakan bahwa: "Di bidang pidana, kejaksaan mempunyai tugas dan wewenang melakukan penuntutan”. Dalam Pasal 1 angka 3 Undang-Undang Nomor 16 Tahun 2004 Tentang Kejaksaan Republik Indonesia menyatakan bahwa: "Penuntutan adalah tindakan penuntut umum untuk melimpahkan perkara ke pengadilan negeri yang berwenang dalam hal dan menurut cara yang diatur dalam Hukum Acara Pidana dengan permintaan supaya diperiksa dan diputus oleh Hakim di sidang pengadilan".

Dalam Pasal 2 Peraturan Kejaksaan Republik Indonesia Nomor 15 Tahun 2020 Tentang Penghentian Penuntutan Berdasarkan Keadilan Restoratif menyatakan bahwa: "Penghentian penuntutan berdasarkan keadilan restoratif dilaksanakan dengan berasaskan:

1. Keadilan;

2. Kepentingan umum;

3. Proporsionalitas;

4. Pidana sebagai jalan terakhir; dan

5. Cepat, sederhana, dan biaya ringan".

\footnotetext{
${ }^{9}$ John Braithwaite, tt, Restorative Justice : Assessing An Immodest Theory And A Pessimistic Theory Draft To Be Summited To Crime And Justice : Review Of Research, University Of Chicago, Press, tanpa tahun, hlm. 5.
} 
Jurnal Magister Hukum Program Pascasarjana Universitas HKBP Nommensen

Volume 02 Nomor o1 Januari 2021 Halaman. 133-142 e-ISSN: 2723-164X p-ISSN: 2722-9858

http://ejournal.uhn.ac.id/index.php/opinion

Penerapan Restorative Justice Dalam Proses Penyelesaian Perkara Tindak Pidana Pengerusakan di Kejaksaan Negeri Pematang Siantar Dihubungkan dengan Peraturan Jaksa Agung No 15 Tahun 2020 tentang Penghentian Penuntutan berdasarkan keadilan Restoratif

Dalam wilayah Kejaksaan Negeri Pematang Siantar terhadap penerapan penerapan restorative justice dalam proses penyelesaian perkara tindak pidana pengerusakan hanya terdapat 1 perkara yang berhasil diselesaikan melalui upaya perdamaian dengan penghentian perkara berdasarkan Peraturan Jaksa Agung No 15 Tahun 2020 tentang Penghentian Penuntutan berdasarkan keadilan restoratif.

Sebagaimana yang diatur di dalam Pasal 30 Ayat (1) Huruf a Undang-Undang Nomor 16 Tahun 2004 Tentang Kejaksaan Republik Indonesia menyatakan bahwa: "Di bidang pidana, kejaksaan mempunyai tugas dan wewenang melakukan penuntutan” Kejaksaan Republik Indonesia menjadi lembaga yang melaksanakan kekuasaan Negara di bidang penuntutan yang dilakukan untuk keadilan, kemanfaatan, dan kepastian hukum dengan tetap menghargai nilai dan prinsip hukum dalam peraturan perundang-undangan. Sebagai lembaga pemerintahan yang melaksanakan tugas penuntutan, maka penuntutan yang dilaksanakan Kejaksaan perlu diarahkan dalam rangka mengikuti reorientasi pembaharuan hukum pidana, mempertimbangkan tingkat ketercelaan, sikap batin pelaku, kepentingan hukum yang dilindungi, kerugian atau akibat yang ditimbulkan, serta memperhatikan rasa keadilan masyarakat termasuk kearifan lokal.

Proses penyelesaian perkara A.n Apul Fernando Sihombing yang disangkakan melanggar 170 ayat (1) KUHP dan Pasal 406 ayat (1) yo Pasal 55 ayat (1) KUHP telah dilakukan dengan upaya perdamaian berupa penghentian penuntutan berdasarkan Keadilan Restoratif dihubungkan dengan PERJAN No 15 Tahun 2020 tentang Penghentian Penuntutan Berdasarkan Keadilan Restoratif yakni tepatnya di Kejaksaan Negeri Pematang Siantar yang berada di lingkup Pengadilan Tinggi Sumatera Utara. Sesuai dengan perbuatan serta kesalahan Terdakwa An Apul Fernando Sihombing penghentian penuntutan berdasarkan keadilan restoratif, sebagaimana dimaksud pada Pasal 3 Ayat (5) Peraturan Jaksa Agung Nomor 15 Tahun 2020 Tentang Penghentian Penuntutan Berdasarkan Keadilan Reatoratif dilakukan oleh Penuntut Umum secara bertanggung jawab dan selanjutnya diajukan secara berjenjang kepada Kepala Kejaksaan Tinggi Sumatera Utara dengan menimbang Pasal Kesatu Pasal 170 ayat (1) KUHP atau Kedua Pasal 406 ayat (1) yo Pasal 55 ayat (1) KUHP.

Dalam Pasal 170 ayat (1) jo Pasal 406 ayat (1) KUHP dipenuhi unsur-unsur antara lain:

1. Barang Siapa

Unsur barang siapa adalah menunjukkan kepada pelaku tindak pidana yang diajukan/menunjuk kepada subyek hukum. KUHP tidak menetapkan berapa jumlah pelaku, akan tetapi pelaku delik ini tidak mungkin dilakukan oleh satu orang saja, akan tetapi "orang banyak", artinya orang orang yang turut ambil bagian dalam tindak kekerasan terhadap orang orang atau barang barang yang dilakukan secara terbuka dan secara bersama -sama. Tetapi ini tidak berarti bahwa semua orang yang ikut serta dalam kerusuhan dapat dipidana. Yang dapat dipidana hanyalah mereka yang secara nyata telah turut melakukan sendiri perbuatan itu. Dalam hal in terdakwa Apul Fernando Sihombing, dkk

2. Terang-terangan

Terang terangan ditafsirkan dimuka umum. Artinya perbuatan tersebut dilakukan bukan ditempat tersembunyi tetapi publik dapat mengakses tempat tersebut, atau orang banyak dapat melihatnya. Pasal ini tidak berlaku terhadap tindak pidana 
kekerasan yang dilakukan ditempat tersembunyi, yang tidak menganggu ketenangan umum, termasuk tindak pidana, dilakukan di jalan raya yang tidak menganggu ketertiban umum atau tidak terusiknya publik. Terang-terangan ditafsir adalah sebagai tempat umum dimanat tempat tersebut publik dapat melihatnya. Bahwa terdakwa I Apul Fernando Sihombing menjadi emosi dan langsung memukul serta membalikkan meja yang ada diruang rapat sehingga meja tersebut rusak dan patah.

3. Secara bersama-sama

Secara bersama sama artinya pelaku pelaku bersekongkol untuk melakukan kekerasan. Bersekongkol dapat dilakukan pada saat kejadian atau sebelum kejadian sudah ada persekongkolan itu untuk melakukan kekerasan. Hal ini terdakwa I Apul Fernando Sihombing menjadi emosi dan langsung memukul serta membalikkan meja yang ada diruang rapat sehingga meja tersebut rusak dan patah, kemudian perbuatan terdakwa Apul Fernando Sihombing diikuti oleh Terdakwa III Bayu Eko Saputra Manik, yang juga langsung mengangkat satu buah kursi besi merk Futura yang ada didalam ruang rapat tersebut dan membantingkannya ke dinding sehingga kursi tersebut rusak dan penyok, setelah itu Terdakwa III Bayu Eko Saputra Manik kembali mengangkat satu buah kursi plastik dan membantingkannya ke lantai hingga kursi plastik tersebut rusak dan patah berantakan di lantai. Selanjutnya Terdakwa II Jessica R Octoria Situmorang juga membalikan dan membanting 1 (satu) buah meja lainnya yang juga ada dalam ruang rapat tersebut, hingga meja tersebut rusak dan pecah,

4. Melakukan kekerasan

Defenisi kekerasan adalah mempergunakan tenaga atau kekuatan jasmani yang tidak kecil serta tidak syah, misalnya memukul dengan tangan atau dengan segala macam senjata, menyepak, menendang, dsb. Dalam hal ini terdakwa Apul Fernando Sihombing, membalikkan dan membanting meja

5. Terhadap orang atau barang

Barang yang diserang atau dirusak adalah barang-barang milik siapa saja tidak tergantung siapa pemiliknya.

4 (empat) buah Meja kerja setengah biro

3 (tiga) buah kursi plastik

2 (dua) buah kursi merek Futura.

Pasal 406 ayat (1) KUHP dengan unsur sebagai berikut :

1. Barang siapa

Unsur barang siapa adalah menunjukkan kepada pelaku tindak pidana yang diajukan/menunjuk kepada subyek hukum, dalam hal ini terdakwa Apul Fernando Sihombing,

2. Dengan sengaja melawan hukum

Perbuatan dengan sengaja melawan hukum dilakukan dengan perbuatan menghancurkan, merusak, membikin tak dapat dipakai atau menghilangkan barang yang seluruhnya dan sebagian milik orang lain. Dalam hal ini perbuatan sengaja melawan hukum adalah Terdakwa I Apul Fernando Sihombing menjadi emosi dan langsung memukul serta membalikkan meja yang ada diruang rapat sehingga meja tersebut rusak dan patah.

3. Melakukan perbuatan menghancurkan, merusakkan, membuat tidak dapat dipakai atau menghilangkan barang sesuatu; Terdakwa I Apul Fernando Sihombing menjadi emosi dan langsung memukul serta membalikkan meja yang ada diruang rapat sehingga meja tersebut rusak dan patah sehingga rusak dan tidak dapat dipakai lagi. 
4. Barang tersebut seluruhnya atau sebagian adalah milik orang lain 4 (empat) buah Meja kerja setengah biro

3 (tiga) buah kursi plastik

2 (dua) buah kursi merek Futura.

Alasan alasan dilaksanakannya penghentian penuntutan dalam perkara an ; Terdakwa I Apul Fernando Sihombing yang disangka melanggar ketentuan kesatu 170 ayat (1) atau kedua pasal 406 ayat (1) yo pasal 55 ayat (1) KUHP, adalah;

1. Para tersangka baru pertama kali melakukan tindak pidana

2. Bahwa tindak pidana dilakukan dengan nilai barang yang nilai kerugian yang ditimbulkan tidak lebih dari Rp 2.500.00o,-

3. Telah melakukan pemulihan kembali pda keadaan semula yang dilakukan tersangka dengan mengganti biaya ditimbulkan dari akibat tindak pidana

4. Telah ada kesepakatan antara para tersangka dengan pihak korban yang dilakukan di Kantor Kejaksaan Negeri Pematang Siantar ( Pasal 4 ayat (1) huruf b,c,e dan g Peraturan Kejaksaan Republik No 15 Than 2020 tentang Penghentian Penuntutan Berdasarkan Keadilan Restoratif )

5. Masyarakat merespon positif

Pasal 5 Ayat (1) Huruf a, b, Ayat (4), Ayat (6) Huruf b, c Peraturan Kejaksaan Republik Indonesia No. 15 Tahun 2020 Tentang Penghentian Penuntutan Berdasarkan Keadilan Restoratif) serta memenuhi kerangka berpikir keadilan restoratif antara lain dengan memperhatikan dan mempertimbangkan keadaan, yaitu :

Penghindaran stigma negative

Penghindaran pembalasan

Kepatutan, kesusilaan dan ketertiban umum

6. Bahwa perbuatan yang dilakukan para tersangka adalah pengerusakan terhadap barang yang dilakukan karena emosi sesaat, karena tuntutan hak mereka berupa pembayaran gaji selama 4 (empat) tahun belum dibayar

7. Dari sisi cost dan benefit, biaya yang ditimbulkan dalam penaganan perkara tidak sebanding dengan manfaat yang akan diperoleh apabila perkara tidak sebanding dengan manfaat yang akan diperoleh apabila perkara ini ditindak lanjuti dengan proses persidangan.

(Pasal 4 Ayat (1) Huruf b, c, e, Ayat (2) Huruf a, b, c, e, dan g Peraturan Kejaksaan Republik Indonesia No. 15 Tahun 2020 Tentang Penghentian Penuntutan Berdasarkan Keadilan Restoratif).

Problematika Penerapan Restorative Justice Dalam Proses Penyelesaian Perkara Tindak Pengerusakan di Lingkup Kejaksaan Negeri Pematang Siantar Dihubungkan dengan Peraturan Jaksa Agung No 15 Tahun 2020 tentang Penghentian Penuntutan berdasarkan keadilan restorative

Penyelesaian perkara melalui sistem peradilan berujung pada vonis pengadilan merupakan suatu penegakan hukum (law enforcement) kearah jalur lambat. Hal ini karena penegakan hukum melalui jarak tempuh mulai dari Kepolisian, Kejaksaan, Pengadilan Negeri, Pengadilan Tinggi bahkan sampai ke Mahkamah Agung, pada akhirnya akan berdampak pada penumpukan perkara. Dengan mengaplikasikan PERJAN No 15 Tahun 2020 dengan cara melakukan penyelesaian melalui di luar pengadilan melalui keadilan restoratif. Tantangan implementasi PERJAN No 15 Tahun 2020 tentang Penghentian Penuntutan Berdasarkan Keadilan Restoratif dalam penerapan menghadapi tantangan antara lain : 
1. Belum adanya kesepahaman keadilan restoratif di antara sesama atau para aparat penegak hukum

2. Kurangnya koordinasi diantara aparat penegak hukum

3. Kurangnya dukungan infrastruktur anggaran dan sarana prasarana

4. Kesiapan sumberdaya manusia. (SDM),

5. Serta perlu dilakukannya penyuluhan terhadap masyarakat dalam upaya melakukan perdamaian.

\section{D.Kesimpulan}

Berdasarkan pembahasan dalam penelitian ini diperoleh kesimpulan antara lain: Bahwa dalam lingkup Kejaksaan Negeri Pematangsiantar penerapan keadilan restoratif dalam penyelesaian perkara pengerusakan telah merujuk kepada asas peradilan cepat, sederhana, dan biaya ringan dalam PERJAN No 15 Tahun 2020 tentang Penghentian Penuntutan Berdasarkan Keadilan Restoratif. Proses perdamaian dilakukan oleh para pihak korban dan para pelaku berdasarkan sukarela. Proses perdamaian dilakukan dengan musyawarah dan mufakat tanpa intimidasi, tanpa paksaan, tanpa tekanan, dan secara sukarela. Saat proses perdamaian, peran Penuntut Umum sebagai fasilitator sangat penting disebabkan Jaksa Penuntut Umum tidak berkepentingan/berketerkaitan dengan tersangka dan korban ataupun perkara, baik secara pribadi, profesi, langsung ataupun tidak. Proses perdamaian dan pemenuhan kewajiban dilakukan 14 (empat belas hari) sejak penyerahan tanggungjawab atas tersangka dan barang bukti (Tahap 2). Belum adanya koordinasi diantara penegak hukum seperti penyidik polisi dan Jaksa Penunutut umum, dan peradilan sebagai bagian dari sistem peradilan pidana (criminal justice system), terutama dalam pahaman keadilan restorative, dukungan infrastuktur, kesiapan sumber daya manusia, dan infrastruktur dan perlunya pemahaman yang seragam dikalangan masyarakarakat tentang upaya perdamaian berupa penghentian, penuntutan yang didasarkan kepada keadilan restorative.

\section{Daftar Pustaka}

Andi Hamzah, 2008, Asas-Asas Hukum Pidana, Edisi Reviai, Rineka Cipta, Jakarta.

John Braithwaite, tt, Restorative Justice: Assessing An Immodest Theory And A Pessimistic Theory Draft To Be Summited To Crime And Justice: Review Of Research, University Of Chicago, Press.

Lili Rasyidi, 2007, Pengantar Filsafat Hukum, Mandar Maju, Bandung.

Mansyur Ridwan, 2010, Mediasi Penal Terhadap Perkara KDRT (Kekerasan Dalam Rumah Tangga), Yayasan Gema Yustisia Indonesia, Jakarta.

Rianto Adi, 2005, Metode Penelitian Sosial dan Hukum, Cet Kedua, Granit, Jakarta.

Satjipto Raharjo, 2009, Hukum dan Perilaku, Hidup Baik Adalah Dasar Hukum Yang Baik, Kompas, Jakarta.

Simamora, Janpatar., Kepastian Hukum Pengajuan Kasasi oleh Jaksa Penuntut Umum Terhadap Vonis Bebas, Jurnal Yudisial, Komisi Yudisial RI, Vol. 7 No. 1 April 2014, hlm. 117 .

Yujun S. Suriasumantri, 1999, Filsafat Ilmu Sebuah Pengantar Populer, Cet Keduabelas, Pustaka Sinar Harapan, Jakarta. 